\title{
Studi Variabilitas Produktivitas Primer Bersih Serta Hubungannya dengan El-Nino Southern Oscillasion (ENSO) dan Indian Ocean Dipole (IOD) di Laut Banda Berdasarkan Data Satelit Aqua MODIS
}

\author{
Ni Luh Novita Aryanti a*, I Gede Hendrawan a, Yulianto Suteja a \\ a Program Studi Ilmu Kelautan, Fakultas Kelautan dan Perikanan, Universitas Udayana, Badung, Bali, Indonesia \\ * Penulis koresponden. Tel.: +6285-792-644-211 \\ Alamat e-mail: novita9i@yahoo.co.id
}

Diterima (received) 7 Agustus 2017; disetujui (accepted) 20 April 2018; tersedia secara online (available online) 22 April 2018

\begin{abstract}
Banda Sea is one of the waters had rich of fish catch. The high catch of fish was related with primary productivity of these waters. Net Primary productivity in the Banda Sea was related with some oceanographic factors such as current, ARLINDO, upwelling and downwelling. The oceanographic factors are influenced by ENSO and IOD. The aim of this research to explained the variability of net primary productivity in Banda Sea and its relation with oceanography factor such as ENSO and monsoon. Data that used in this research were data from MODIS satellite and for analysis of net primary productivity data used Vertically Generalized Production Model (VGPM). The relation of net primary productivity with ENSO and IOD can used pearson correlation method. The result of net primary productivity value in Banda Sea was about $100 \mathrm{gCm}^{-2} \mathrm{day}^{-1}-1200 \mathrm{gCm}^{-2} \mathrm{day}^{-1}$, with the highest apex net primary productivity in August precisely in the east season. The high value of net primary productivity due to upwelling in the season. The value of net primary productivity in west season was decreased. This condition caused by the downwelling of the season. The region with the highest net primary productivity value was the northeast of Banda Sea and the region with lowest net primary productivity value was the western of Banda Sea. The relationship between ENSO with net primary productivity in Banda Sea classified in medium correlation with value 0,556, while relationship between IOD and net primary productivity classified in weak correlation with value 0,23 .
\end{abstract}

Keywords: Banda Sea; net primary productivity; ENSO; IOD

\begin{abstract}
Abstrak
Laut Banda merupakan salah satu perairan yang kaya akan hasil tangkapan ikannya. Hasil tangkapan ikan yang tinggi sangat terkait dengan produktivitas primer perairan tersebut. Produktivitas primer di Laut Banda tidak terlepas dari adanya factor oseanografi seperti arus, ARLINDO, upwelling dan downwelling. Faktor oceanografi tersebut dipengaruhi oleh ENSO dan angin musim. Tujuan dari penelitian ini adalah mengetahui variabilitas produktivitas primer bersih di Laut Banda serta hubungannya dengan ENSO dan IOD. Data yang digunakan dalam penelitian ini yaitu data satelit MODIS dan untuk analisis data produktivitas primer bersih menggunakan model Vertically Generalized Production Model (VGPM). Dalam mencari hubungan produktivitas primer bersih dengan ENSO dan IOD yaitu menggunakan korelasi pearson. Dari perhitungan tersebut didapatkan nilai produktivitas primer bersih di Laut Banda berkisar $100 \mathrm{gC} \mathrm{m}^{-2} \mathrm{day}^{-1}-1200 \mathrm{gC} \mathrm{m}^{-2}$ day-1 $^{-1}$, dengan puncak tertinggi produktivitas primer bersih berada pada bulan Agustus tepatnya pada musim timur. Tingginya nilai produktivitas primer bersih dikarenakan adanya peristiwa upwelling pada musim tersebut. Pada musim barat nilai produktivitas primer bersih mulai menurun. Hal ini diduga diakibatkan oleh adanya peristiwa downwelling pada musim tersebut. Wilayah yang memiliki nilai produktivitas primer bersih tertinggi yaitu wilayah timur Laut Banda dan wilayah yang memiliki nilai produktivitas primer bersih terendah yaitu wilayah Laut Banda bagian barat. Hubungan antara ENSO dengan produktivitas primer bersih di Laut Banda termasuk dalam kategori sedang dengan nilai korelasinya yaitu 0,556 sedangkan hubungan antara IOD dan produktivitas primer bersih tergolong dalam kategori lemah dengan nilai korelasinya yaitu 0,23 .
\end{abstract}

Kata Kunci: Laut Banda; produktivitas primer bersih; ENSO; IOD 


\section{Pendahuluan}

Laut Banda merupakan salah satu laut di Indonesia yang memiliki kekayaan hayati yang tinggi. Hal ini dapat dilihat dari hasil tangkapan ikannya yang begitu besar dan merupakan daerah penangkapan ikan terbesar di Indonesia (Yulia, 2013). Hasil tangkapan ikan di Laut Banda pada tahun 2006 berkisar 437.183,40 ton (Sukresno dan Suniada, 2016). Hasil tangkapan ikan yang tinggi sangat bergantung dari nilai produktivitas primer bersih perairan tersebut. Perairan dengan produktivitas primer bersih yang tinggi akan menghasilkan sumber daya laut yang tinggi dan melimpah (Kemili dan Putri, 2012).

Produktivitas primer bersih merupakan karbon yang tersedia untuk tingkat trofik yang lebih tinggi yang dapat dihasilkan dalam satu meter kuadrat kolom air per hari $(\mathrm{gCm}-2$ per hari) (Levinton, 2013). Produktivitas primer bersih di suatu perairan sangat dipengaruhi oleh adanya faktor nutrient, cahaya, klorofil-a, Photosintetically Active Radiation (PAR) dan suhu permukaan laut (SPL). Nutrient dibutuhkan untuk pertumbuhan fitoplankton, cahaya dibutuhkan untuk proses fotosintesis fitoplankton, suhu permukaan laut dibutuhkan untuk laju fotosintesis dan distribusi fitoplankton di kolom perairan, serta klorofil-a sebagai pigmen fitoplankton yang menentukan nilai produktivitas primer bersih perairan (Nontji, 2006 dalam Fauzia, 2011).

Produktivitas primer bersih di Laut Banda dipengaruhi oleh adanya pengaruh faktor oseanografi seperti musim, arus lintas Indonesia (ARLINDO) yang mempengaruhi massa air dan terjadinya proses mixing di Laut Banda, serta ada beberapa pengaruh seperti El-nino Southern Oscillasion (ENSO) dari Samudra Pasifik (Sukresno dan Kasa, 2008). Faktor pendukung lain yang memiliki pengaruh terhadap kondisi oseanografi di Laut Banda adalah Indian Ocean Dipole (IOD) (Yulia, 2013).

Produktivitas primer bersih dapat diestimasi dengan menggunakan data penginderaan jarak jauh (Ishizaka et al., 2010; Joo et al., 2015; Lee et al., 2015; Yen and Lu, 2016; Deng et al., 2017; González-Rodríguez et al., 2012; Shang et al., 2010). Salah satu citra satelit yang dapat digunakan untuk mengestimasi produktivitas primer bersih di perairan adalah satelit Aqua dengan sensor MODIS (Moderate Resolution Imaging
Spectroradiometer) level 3 dengan resolusi $4 \mathrm{~km}$. Data citra MODIS level 3 merupakan data yang telah terkoreksi secara radiometrik dan atmosferik. Data tersebut sudah memiliki informasi seperti lintang, bujur, daratan, awan dan nilai estimasi konsentrasi klorofil fitoplankton perairan. Banyak penelitian yang telah dilakukan di Laut Banda dengan menggunakan citra satelit Aqua MODIS (Sediadi, 2010; Yulia, 2013; Waileruny et al., 2014; Pusparini et al., 2017; Tadjuddah dan Mustafa, 2017).

Penelitian mengenai hubungan produktivitas primer bersih di Laut Banda dengan fenomena ENSO telah dilakukan oleh Sukresno dan Suniada (2016), didapatkan bahwa hubungan ENSO dan produktivitas primer bersih memiliki korelasi sebesar 0,33 , dimana data yang diambil pada saat itu merupakan data tiga tahun yaitu tahun 2004 2006. Kemili dan Putri (2012) mendapatkan nilai produktivitas primer bersih di Laut Banda tertinggi saat terjadinya ENSO pada tahun 2002, 2004, dan 2006 sebesar $1600 \mathrm{mgCm}^{-2}$ per hari sedangkan pada tahun-tahun normal yaitu tahun 2001 dan 2003 produktivitas primer bersih hanya berkisar $1250 \mathrm{mgCm}^{-2}$ per hari. Penelitian yang dilakukan oleh Yulia (2013) di Laut Banda menyebutkan bahwa pada saat IOD positif suhu permukaan laut menjadi minimum namun tidak dijelaskan keterkaitannya dengan produktivitas primer bersih di perairan tersebut.

Gambaran mengenai variasi perubahan produktivitas primer bersih yang terjadi di Laut Banda dapat diamati secara spasial dengan melihat sebaran spasial dari variasi rata-rata produktivitas primer bersih. Adanya faktor oseanografi seperti ENSO dan IOD diindikasikan memberikan pengaruh terhadap produktivitas primer bersih di Laut Banda. Oleh karena itu kajian variabilitas produktivitas primer bersih dan hubungannya dengan ENSO dan IOD di Laut Banda sangat penting dilakukan untuk dapat mengidentifikasi fenomena-fenomena yang terjadi.

\section{Metode Penelitian}

\subsection{Waktu dan Tempat}

Wilayah penelitian berada pada koordinat $3^{\circ}-8^{\circ} \mathrm{LS}$ dan $124^{\circ}-132^{\circ}$ BT (Gambar 1). Data satelit Aqua MODIS level 3 dari bulan Januari 2003 sampai dengan Desember 2016 digunakan untuk melakukan analisis NPP di Laut Banda. 


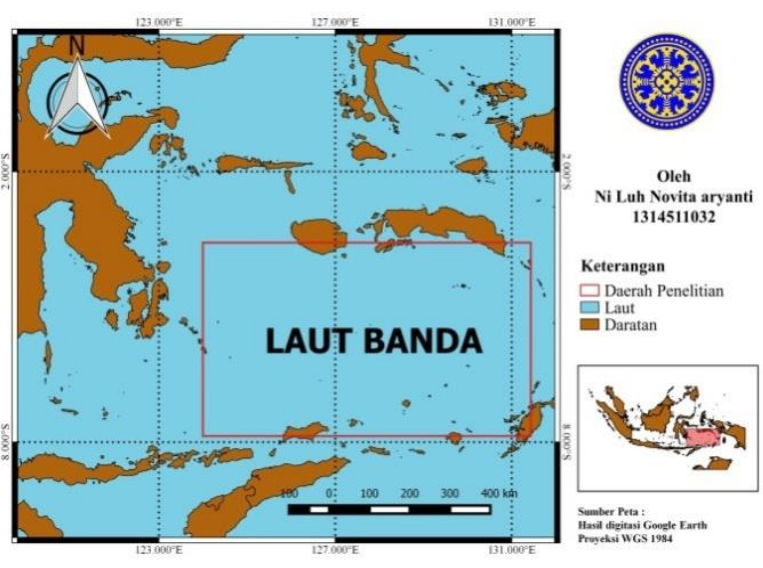

Gambar 1. Lokasi Penelitian di Laut Banda.

Untuk mengetahui distribusi produktivitas primer bersih di Laut Banda secara lebih spesifik, maka dilakukan pembagian daerah seperti terlihat pada Gambar 2. Pembagian daerah di Laut Banda dilakukan secara acak (random) yaitu daerah $\mathrm{A}, \mathrm{B}$, C, D, E, F, G, H, dan I.

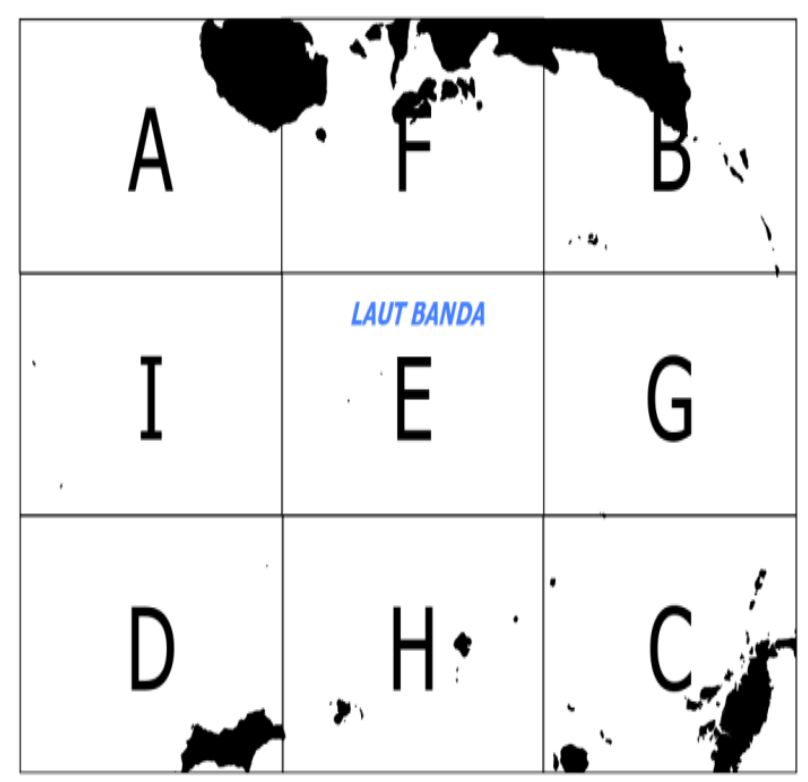

Gambar 2. Pembagian wilayah Laut Banda

\subsection{Data}

Data yang digunakan pada penelitian ini tercantum pada Tabel 1. Data SPL, PAR, Chl-a diunduh dari Aqua MODIS melalui situs www.oceancolor.gsfc.nasa.gov yaitu, data level 3 composite bulanan denganresolusi spasial $4 \mathrm{~km}$. Data day lenght didapatkan dari National Oceanic and Atmospheric Administration (NOAA).
Tabel 1

Data Penelitian

\begin{tabular}{|c|c|c|c|c|}
\hline No & Data & Sumber Data & Cakupan & Waktu \\
\hline 1 & SST & $\begin{array}{l}\text { Satelit MODIS- } \\
\text { Aqua } \\
\text { Oseancolor.gsfc } \\
\text {.nasa.gov }\end{array}$ & $\begin{array}{c}\text { Level } 3 \\
\text { (Komposit } \\
\text { Bulanan), } \\
\text { resolusi } 4 \mathrm{~km}\end{array}$ & $\begin{array}{c}2003- \\
2016\end{array}$ \\
\hline 2 & Chl-a & $\begin{array}{l}\text { Satelit MODIS- } \\
\text { Aqua } \\
\text { Oseancolor.gsfc } \\
\text {.nasa.gov }\end{array}$ & $\begin{array}{l}\text { Level } 3 \\
\text { (Komposit } \\
\text { Bulanan), } \\
\text { resolusi } 4 \mathrm{~km}\end{array}$ & $\begin{array}{c}2003- \\
2016\end{array}$ \\
\hline 3 & PAR & $\begin{array}{l}\text { Satelit MODIS- } \\
\text { Aqua } \\
\text { Oseancolor.gsfc } \\
\text {.nasa.gov }\end{array}$ & $\begin{array}{c}\text { Level } 3 \\
\text { (Komposit } \\
\text { Bulanan), } \\
\text { resolusi } 4 \mathrm{~km}\end{array}$ & $\begin{array}{c}2003- \\
2016\end{array}$ \\
\hline 4 & $\begin{array}{c}\text { Day } \\
\text { Length }\end{array}$ & $\begin{array}{l}\text { National Oceanic } \\
\text { and Atmospheric } \\
\text { Administration } \\
\text { (NOAA) }\end{array}$ & - & $\begin{array}{c}2003- \\
2016\end{array}$ \\
\hline 5 & IOD & $\begin{array}{l}\text { http://wwww.jamstec } \\
\text {.go.jp/frcgc/researc } \\
\text { h/d1/iod/DATA/d } \\
\text { mi.monthly.txt }\end{array}$ & Data Bulanan & $\begin{array}{c}2003- \\
2016\end{array}$ \\
\hline
\end{tabular}

Data SPL, PAR, Chl-a yang telah di unduh dilakukan pemotongan citra (cropping) sesuai dengan lokasi penelitian dengan menggunakan software SAGA GIS 2.1.2. Data tersebut kemudian digunakan untuk melakukan perhitungan NPP.

\subsection{Analisis Data}

2.3.1. Perhitungan Produktivitas Primer Bersih / Net Primary Productivity (NPP)

Metode yang digunakan untuk menghitung Net Primary Productivity (NPP) adalah metode Vertically Generalized Production Model (VGPM). Metode VGPM adalah salah satu metode yang digunakan untuk menghitung produktivitas primer bersih di laut global, dimana pada umumnya produksi primer berlangsung dari permukaan menuju kedalaman dimana $1 \%$ cahaya permukaan masih tersedia (zona eufotik). Persamaan yang digunakan dalam metode VGPM (Behrenfeld and Falkowski, 1997) dijelaskan dalam persamaan 1:

$\sum P P=0.6615 \times P_{o p t}^{B} \times \frac{E_{0}}{E_{0}+4.1} \times D_{e z} \times C_{S A T} \times D L$ 
Keterangan:

$$
\begin{aligned}
& \sum P P=\text { Daily carbon fixation integrated from } \\
& \text { the surface to } \mathrm{Ze}\left(\mathrm{mgC} / \mathrm{m}^{2} / \text { day }\right) \\
& D L=\text { Lama siang hari (h/day) } \\
& C_{S A T}=\text { Nilai dari konsentrasi Klorofil-a } \\
& \text { permukaan yang didapat dari data } \\
& \text { satelit }\left(\mathrm{mgChl} / \mathrm{m}^{3}\right) \\
& { }_{P}{ }^{B}=\text { Tingkat maksimum fiksasi karbon } \\
& \text { opt dalam kolom air dan oleh } \\
& \text { Behrenfeld and Falkowski (1997) } \\
& \text { menyatakan sebagai tujuh urutan } \\
& \text { fungsi polinom SST [mgC (mgChl)- } \\
& { }^{1} \mathrm{~h}^{-1} \text {. Nilai tersebut dapat dihitung } \\
& \text { dari hubungan keberagaman suhu } \\
& \text { dengan klorofil-a sehingga dapat } \\
& \text { dinyatakan melalui persamaan } \\
& \text { sebagai berikut: } \\
& P_{\text {opt }}^{B}= \begin{cases}1.13 & \text { if } T<-1.0 \\
4.00 & \text { if } T>28.5 \\
P_{\text {opt }}^{B} & \text { otherwise }\end{cases} \\
& P_{\text {opt }}^{B}=1.2956+2.749 \times 10^{-1} T+6.17 \times 10^{-2} T^{2} \\
& -2.05 \times 10^{-2} T^{3}+2.462 \times 10^{-3} T^{4} \\
& -1.348 \times 10^{-4} T^{5}+3.4132 \times 10^{-6} T^{6} \\
& -3.27 \times 10^{-8} T^{7} \\
& T=\text { Suhu Permukaan Laut }\left({ }^{\circ} \mathrm{C}\right) \\
& \begin{array}{c}
D_{e z}=\text { Kedalaman }(\mathrm{m}) \text { zona euphotik }(Z e), \\
\text { dihitung dari } C_{S A T}
\end{array} \\
& Z e= \begin{cases}568.2\left(C_{\text {TOT }}\right)^{-0.746} & \text { if } Z e<102 \\
200.0\left(C_{\text {TOT }}\right)^{-0.293} & \text { if } Z e>102\end{cases}
\end{aligned}
$$

dimana $C_{T O T}$ merupakan nilai klorofil total

$$
C_{T O T}= \begin{cases}38.0\left(C_{S A T}\right)^{0.425} & \text { if } C_{S A T}<1.0 \\ 40.2\left(C_{S A T}\right)^{0.507} & \text { if } C_{S A T}>1.0\end{cases}
$$

$E_{0}=$ Sea surface daily PAR (mol quanta/m²/day)

$E_{0}= \begin{cases}0 & \text { if } P A R<0 \\ E_{0} & \text { Otherwise }\end{cases}$

$$
E_{0}=0.66125 \times \frac{P A R}{P A R+4.1}
$$

Hasil dari perhitungan NPP adalah rata-rata NPP bulanan dan musiman. Pembagian nilai NPP secara musiman ini menurut Wyrtki (1961) yaitu musim timur (Juni-Agustus), musim peralihan II (September-November), musim peralihan I (MaretMei) dan musim barat (Desember-Februari).

Untuk melihat penyimpangan NPP terhadap kondisi normal maka dilakukan perhitungan anomali NPP. Perhitungan anomali NPP didapatkan dari nilai NPP pada kondisi sekarang (NPPs) dikurangi NPP pada kondisi normal $\left(\mathrm{NPPN}_{\mathrm{N}}\right)$. NPPN merupakan rata-rata bulanan NPP selama 14 tahun. Anomali NPP dihitung berdasarkan persamaan 8 :

$$
\text { Anomali } N P P=N P P_{S}-N P P_{N}
$$

\subsubsection{Perhitungan Indek ENSO}

Untuk menghitung indek ENSO maka dilakukan (2) perhitungan anomali suhu permukaan laut di wilayah Nino 3.4. Nino 3.4 berada di sentral pasifik dengan koordinat yaitu $5^{\circ}$ LU $-5^{\circ}$ LS dan $120^{\circ}$ BB- $170^{\circ}$ BB. Perhitungan anomali suhu permukaan laut (SPLA) didapatkan dari nilai SPL kondisi sekarang (SPLR) dikurangi dengan SPL pada kondisi normal (SPLN), dimana SPLR merupakan rata-rata SPL bulanan sedangkan SPLN merupakan rata-rata SPL bulanan selama 14 tahun. Perhitungan dilakukan dengan menggunakan data citra Aqua MODIS sehingga didapatkan rumus seperti terlihat pada persamaan 9 (NOAA, 2016):

$$
S P L_{A}=S P L_{R}-S P L_{N}
$$

Untuk mereduksi sinyal frekuensi yang lebih tinggi (higher frequency) seperti pengaruh Madden Julian Oscillation (MJO) maka dilakukan filter pada indek ENSO dengan menggunakan metode low pass filter (Hidayat dan Ando, 2014)

2.3.3. Hubungan ENSO, IOD, dan Produktivitas primer bersih/Net Primary Productivity (NPP)

\section{a. Analisis Korelasi Temporal}

Data yang digunakan dalam mencari hubungan antara ENSO, IOD dan Produktivitas primer bersih yaitu data anomali produktivitas primer bersih yang sudah difilter terlebih dahulu dengan menggunakan filter moving average. Filter moving average merupakan filter yang digunakan untuk menghaluskan deret waktu untuk memperkirakan 
atau menyoroti tren yang mendasarinya (Cai et al., 2012). Data anomali NPP yang sudah di filter kemudian di korelasikan dengan indek ENSO maupun dengan indek IOD dengan menggunakan korelasi pearson seperti terlihat pada persamaan 10 (So'langi, 2015):

$$
r=\frac{\sum_{i=1}^{n} x_{i} y_{i}-(1 / n)\left(\sum_{i=1}^{n} x_{i}\right)\left(\sum_{i=1}^{n} y_{i}\right)}{\sqrt{\left[\sum_{i=1}^{n} x_{i}^{2}-(1 / n)\left(\sum_{i=1}^{n} x_{i}\right)^{2}\left[\sum_{i=1}^{n} y_{i}^{2}-(1 / n)\left(\sum_{i=1}^{n} y_{i}\right)^{2}\right]\right.}}
$$

Keterangan:

$r=$ korelasi

$n=$ jumlah data

$x=$ indek ENSO atau IOD

$y=\mathrm{NPP}$

\section{b. Analisis Korelasi Spasial}

Korelasi antara data produktivitas primer bersih dengan ENSO dan IOD dicari melalui korelasi di setiap pixel citra NPP (data bulanan selama 14 tahun), sehingga akan didapatkan peta korelasi antara produktivitas primer bersih dengan indeks ENSO dan peta korelasi antara produktivitas primer bersih dan indeks IOD. Peta korelasi tersebut akan menjelaskan produktivitas primer bersihyang dipengaruhi oleh IOD dan ENSO di Laut Banda dalam bentuk bulanan serta musiman.Berikut ini merupakan gambaran dari analisis sebaran korelasi spasial antara kosentrasi NPP terhadap ENSO dan IOD (Gambar 3). Sedangkan interpretasi nilai koefisien korelasi berdasarkan Sugiyono (2011; Tabel 2).

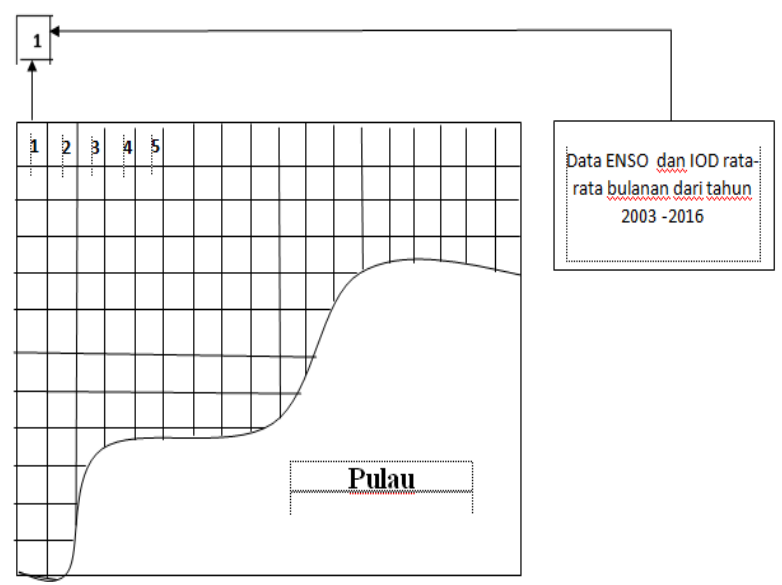

Gambar 3. Analisis korelasi spasial antara NPP, indeks Nino 3.4 dan IOD

\section{Hasil dan Pembahasan}

3.1 Variabilitas Produktivitas primer bersih (NPP) di Laut Banda

Variabilitas produktivitas primer bersih (NPP) di Laut Banda selama 14 tahun dapat dilihat pada Gambar 4. Rata-rata NPP di Laut Banda yaitu sebesar $100 \mathrm{mgC} \mathrm{m}^{-2}$ day-1-1200 $^{-1} \mathrm{mC} \mathrm{m}^{-2} \mathrm{day}^{-1}$.NPP tertinggi terdapat pada bulan Agustus 2015 yaitu $1026.7 \mathrm{mgCm}^{-2}$ day $^{-1}$ dan terendah pada bulan Desember 2010 yaitu $207.7 \mathrm{mgC} \mathrm{m}^{-2} \mathrm{day}^{-1}$. Secara umum NPP di Laut Banda setiap tahunnya mengalami peningkatan dari bulan Juni dan mencapai puncaknya pada bulan Agustus. Namun demikian, terjadi penurunan dari bulan September sampai bulan Mei. NPP pada penelitian ini memiliki pola yang serupa dengan penelitian yang telah dilakukan oleh Sukresno dan Suniada (2016). NPP sangat ditentukan oleh konsentrasi klorofil-a

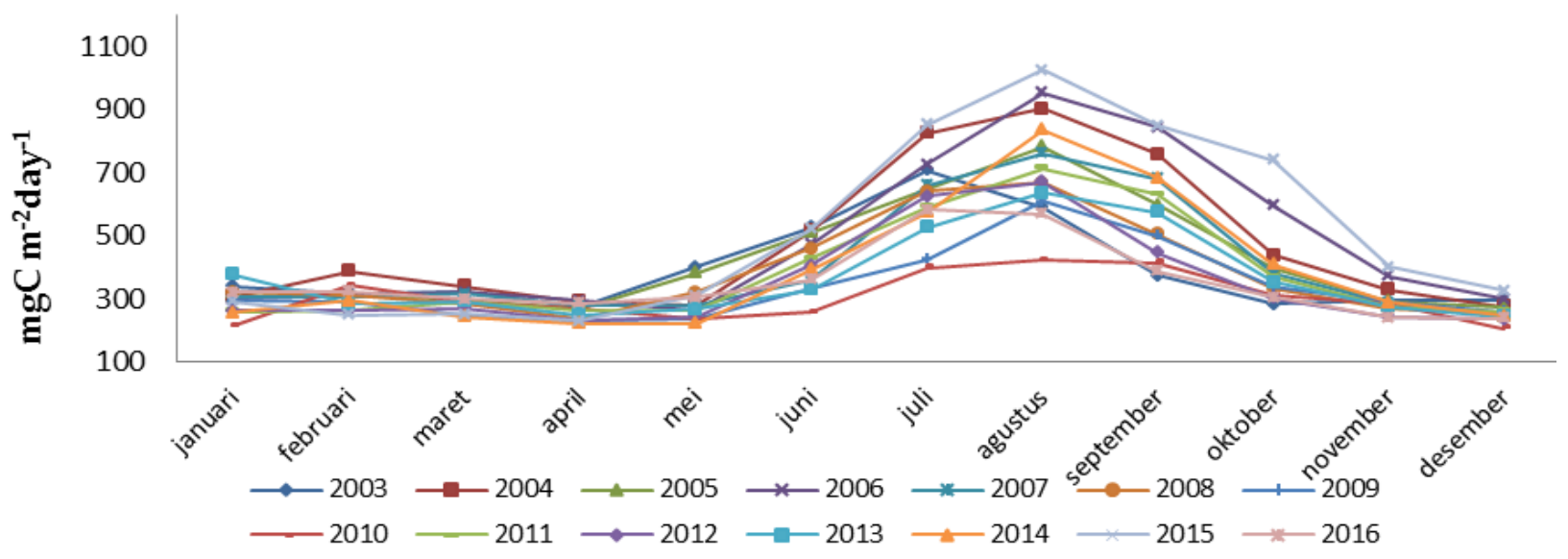

Gambar 4. Rata-rata Bulanan produktivitas primer bersih di Laut Banda (2003-2016) 


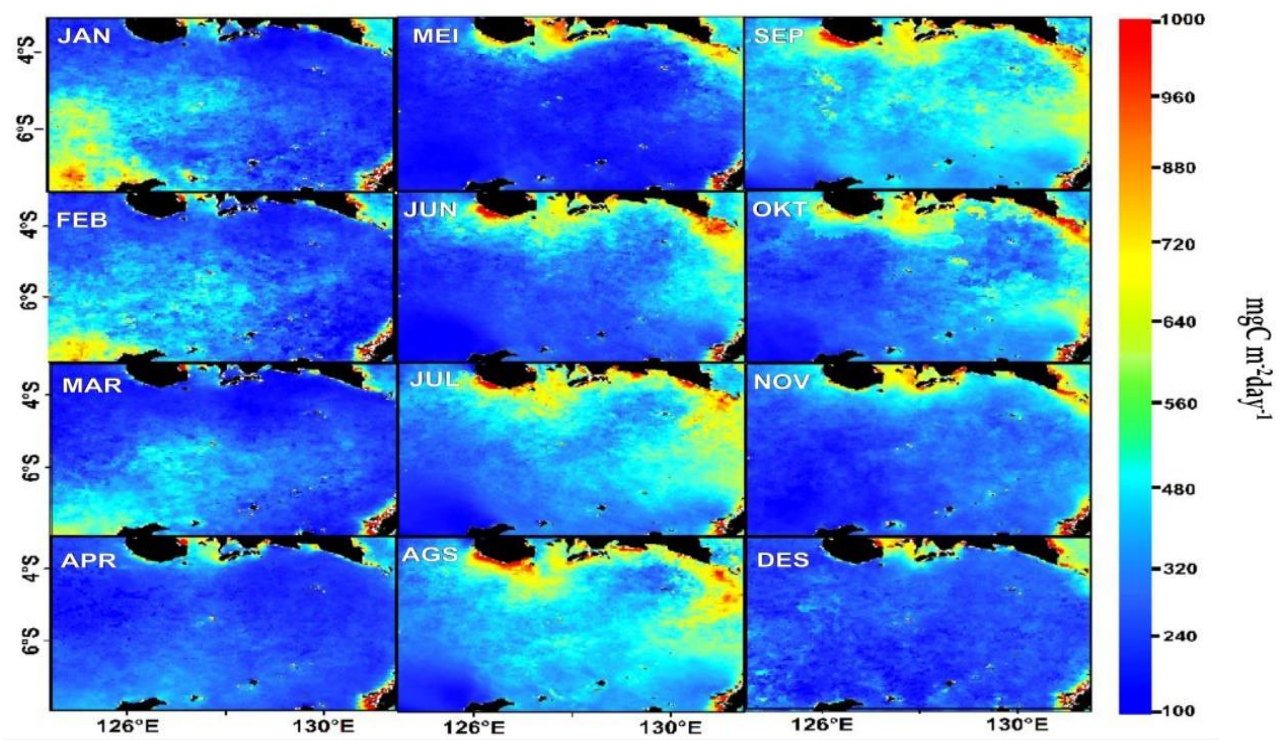

Gambar 5. Rata-rata spasial bulanan produktivitas primer bersih di Laut Banda (2003-2016)

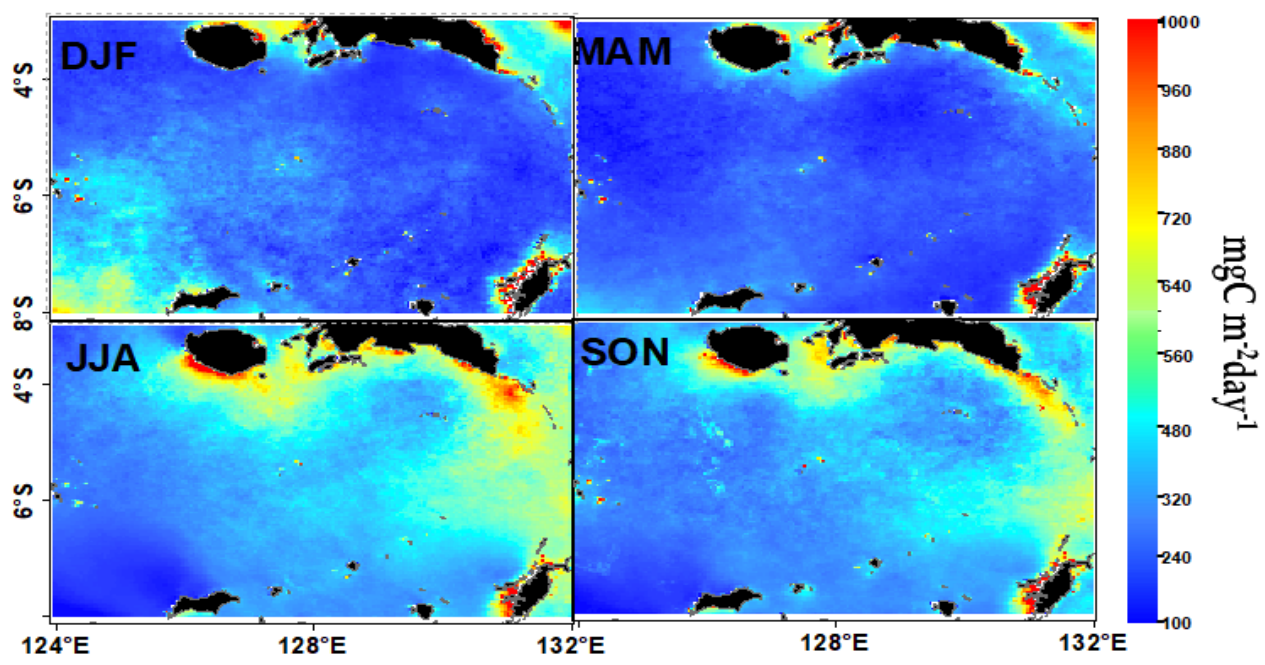

Gambar 6. Produktivitas primer bersih secara musiman

pada suatu perairan. Konsentrasi klorofil-a di Laut Banda sangat dipengaruhi oleh upwelling yang terjadi di perairan tersebut (Tarigan, 2010).

Secara spasial rata-rata NPP dari bulan Januari hingga Desember dapat dilihat pada Gambar 5. Rata-rata spasial bulanan NPP tertinggi terjadi pada bulan Agustus dan terendah pada bulan April, dimana hal tersebut dapat dilihat dari tingginya NPP di sekitar pesisir Pulau Maluku, Teluk Ambon, Pulau Jamdena dan pulau kecil di sekitarnya. Tingginya NPP pada wilayah pesisir Pulau Maluku, Teluk Ambon, Pulau Jamdena dan pulau kecil di sekitarnya di bulan Agustus disebabkan oleh adanya upwelling yang disebabkan oleh ekman transport. Gordon dan Susanto (2001) menyatakan bahwa upwelling maksimum terjadi pada bulan Agustus. Pada bulan April nilai NPP mengalami penurunan pada wilayah pesisir Pulau Maluku, Teluk Ambon, Pulau Jamdena dan pulau kecil disekitarnya. Rendahnya NPP pada bulan April diduga karena adanya fenomena downwelling. Menurut Ratnawati et al., 2016 fenomena downwelling terjadi pada musim barat (Desember-Maret) sehingga diduga pada bulan April yang mulai masuk pada musim peralihan I masih terkena dampak dari fenomena downwelling yang terjadi pada musim barat. Secara musiman NPP dapat dilihat pada Gambar 6. NPP tertinggi terjadi pada musim timur, sedangkan nilai terendah terjadi pada musim peralihan I.

Pada musim timur peningkatan nilai NPP terjadi pada pesisir Pulau Maluku, Teluk Ambon, 


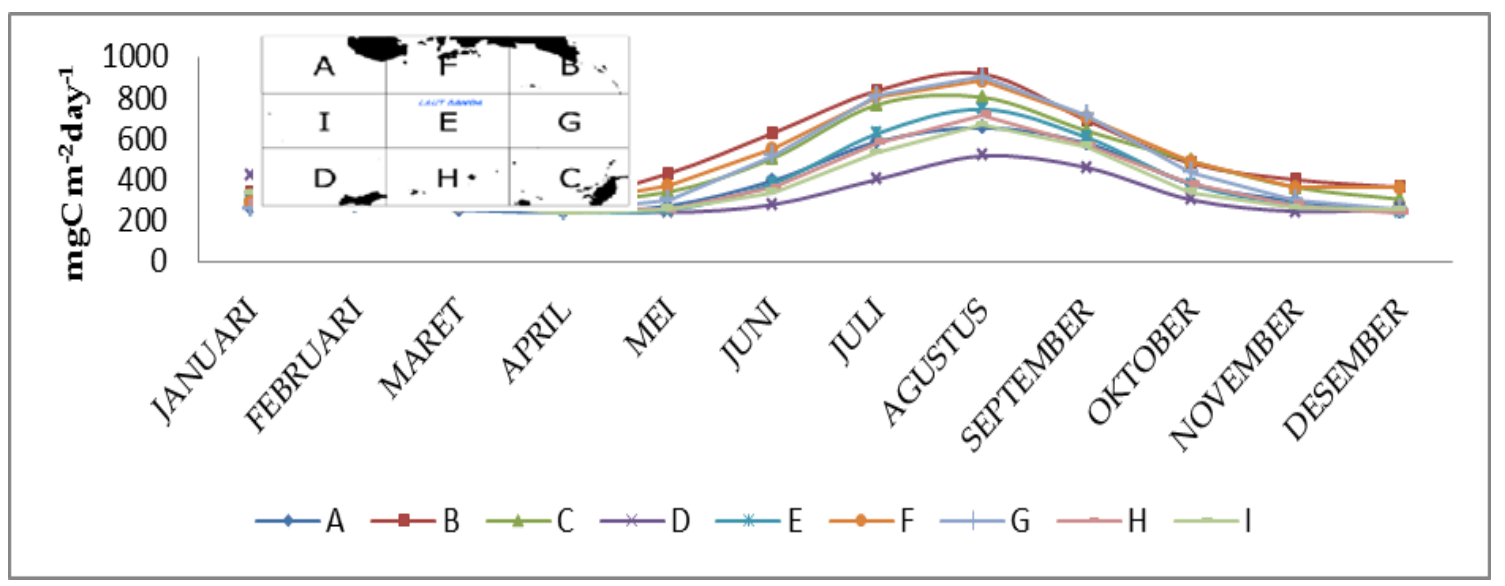

Gambar 7. Produktivitas primer bersih di setiap daerah Laut Banda (A, B, C, D, E, F, H, I)

Pulau Jamdena dan pulau kecil disekitarnya. Tingginya nilai produktivitas primer bersih pada musim tersebut diduga diakibatkan oleh adanya pengaruh upwelling. Pernyataan ini didukung oleh penelitian Kemili dan Putri (2012) yang menyebutkan bahwa peningkatan nilai produktivitas primer bersih disebabkan oleh proses upwelling pada saat musim timur dengan peningkatan produktivitas primer bersih mencapai 200-800 $\mathrm{mgCm}^{-2}$ per hari. Pada saat angin musim timur berhembus, massa air dari Laut Banda dibawa keluar dalam jumlah yang besar sehingga terjadi kekosongan massa air yang akan diisi oleh air dari lapisan dalam Ekman pumping di Laut Banda.

Pada Gambar 6 terlihat jelas bahwa terjadi penurunan NPP pada musim barat dan peralihan I di sekitar pesisir Pulau Maluku dan Teluk Ambon. Rendahnya NPP pada saat Musim Barat dan peralihan I diakibatkan oleh adanya pengaruh proses downwelling. Pernyataan ini didukung oleh penelitian Ratnawati et al. (2016) yang menyatakan bahwa proses upwelling dan downwelling di Laut Banda terjadi secara bergantian, dimana pada musim barat yaitu bulan Desember sampai Maret merupakan proses berlangsungnya downwelling dengan ekman transport yang menjauhi pantai. Proses downwelling menyebabkan kekosongan massa air pada dasar perairan sehingga menyebabkan massa air di permukaan turun ke dasar perairan. Schalk (1987), menyatakan bahwa pergantian musim dapat mengakibatkan perubahan kondisi hidrologi perairan terutama pada musim barat, dimana proses downwelling di Laut Banda menyebabkan stabilitas vertikal di kolom perairan menjadi tinggi. Pernyataan tersebut diperkuat oleh Ilahude (1990), yang menyebutkan bahwa Laut Banda mendapatkan banyak masukan dari Laut Jawa yang diakibatkan oleh ARMONDO (Arus Monsoon Indonesia) yang menyebabkan terjadinya surplus dan untuk mengimbangi adanya surplus tersebut terjadilah downwelling yang diikuti oleh arus ke Laut Banda.

Berdasarkan Gambar 7 dapat dilihat bahwa daerah yang memiliki NPP tertinggi yaitu daerah sebelah timur (daerah B), sedangkan daerah dengan nilai NPP yang paling rendah adalah daerah yang terletak di sebelah barat Laut Banda (daerah D). Tingginya NPP di daerah B diakibatkan oleh adanya pengaruh dari proses ekman transport yang mengakibatkan proses upwelling di wilayah tersebut (Ratnawati et al., 2016).

Proses Ekman transport di bagian timur Laut Banda terjadi ketika angin pasat yang berhembus dari timur pasifik mendorong arus yang membawa massa air ke arah barat Laut Banda sehingga spiral ekman membentuk sudut $90^{\circ} \mathrm{ke}$ kiri terhadap arah angin yang menyebabkan massa air permukaan di pantai akan bergerak menuju laut lepas. Berbeloknya arah arus ke arah kiri dikarenakan Laut Banda berada di belahan bumi bagian selatan. Mekanisme tersebut menyebabkan terbentuknya kemiringan antara daerah pantai dan laut lepas yang diakibatkan oleh penumpukan massa air di bagian barat. Untuk mengimbangi perbedaan ketinggian muka air, massa air dari lapisan bawah pantai bergerak ke lapisan atas sehingga terjadi penurunan lapisan termoklin di bagian barat dan kenaikan di bagian timur (Martono, 2016). Selain adanya faktor upwelling, faktor lain yang diduga sebagai penyebab tingginya nilai NPP di bagian pesisir adalah konsentrasi klorofil-a. NPP dan klorofil-a memiliki 
hubungan yang sangat kuat dan berbanding lurus dengan nilai korelasinya yaitu 0,98 . Hal tersebut menunjukan bahwa semakin tinggi klorofil-a maka NPP semakin meningkat. Febriaty et al. (2013) dan Merina (2016) menyatakan kandungan klorofil-a lebih banyak ditemukan pada lapisan permukaan di dekat pesisir.

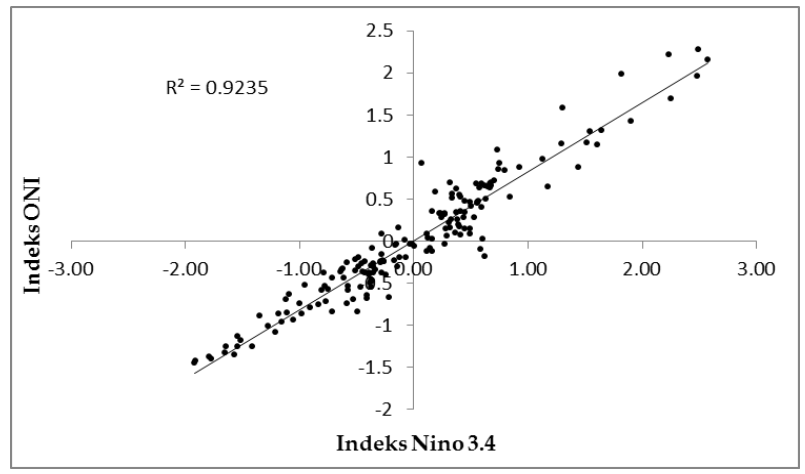

Gambar 8. Indeks Nino 3.4 dan Indeks ONI

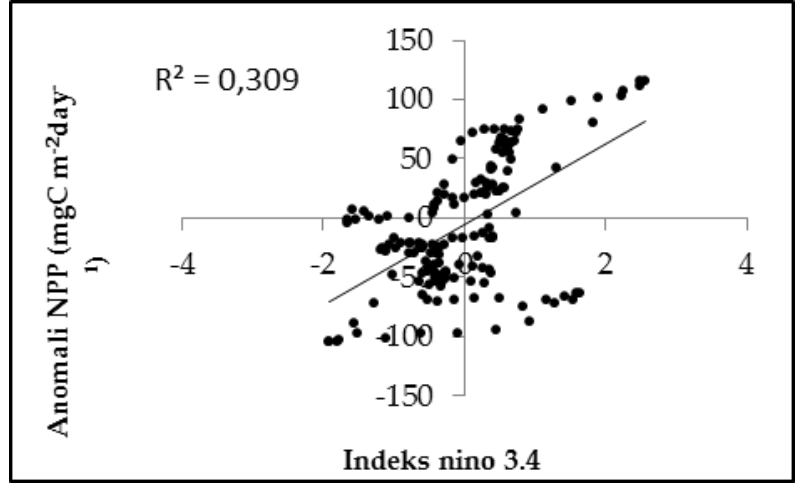

Gambar 9. Hubungan antara ENSO dan anomali produktivitas primer bersih

Daerah Laut Banda yang memiliki NPP terendah terdapat pada bagian barat Laut Banda (daerah D). Rendahnya NPP di daerah D dipengaruhi oleh proses ekman transport yang menyebabkan terjadinya penumpukan massa air di bagian barat Laut Banda sehingga mengakibatkan downwelling di perairan tersebut.

Mekanisme ekman transport di Laut Banda menyebabkan terjadinya penumpukan massa air di barat Laut Banda sehingga massa air di barat Laut Banda lebih hangat di bandingkan pada timur Laut Banda (Martono, 2016). Nilai suhu yang semakin turun mengindikasikan meningkatnya upwelling yang terjadi di daerah tersebut. Sukresno dan Suniada (2016) menjelaskan bahwa suhu berbanding terbalik dengan nilai klorofil yang diakibatkanproses upwelling. Hal tersebut didukung oleh penelitian Kakunde (2001) dalam Sediadi (2010) yang menyatakan bahwa suhu di bagian Barat Laut Banda pada saat musim timur turun sampai $1^{\circ} \mathrm{C}$, sedangkan di wilayah timur Laut Banda turun sampai 2,5 $5^{\circ} \mathrm{C}$.

\subsection{Hubungan ENSO dan IOD dengan Produktivitas primer bersih (NPP)}

Hasil perhitungan indeks ENSO dengan nilai indeks ONI menyatakan hubungan yang sangat kuat dengan nilai korelasinya sebesar 0,96 (Gambar 8). Hasil perhitungan hubungan ENSO dengan NPP di Laut Banda menunjukkan bahwa adanya hubungan ENSO terhadap produktivitas primer di Laut Banda dengan nilai korelasi yang tergolong sedang. Nilai koefisien determinasi antara ENSO dan produktivitas primer bersih sebesar 0,31, dengan nilai korelasi sebesar 0,56 (Gambar 9). Nilai korelasi ENSO dan NPP yang tergolong sedang dikarenakan terjadinya

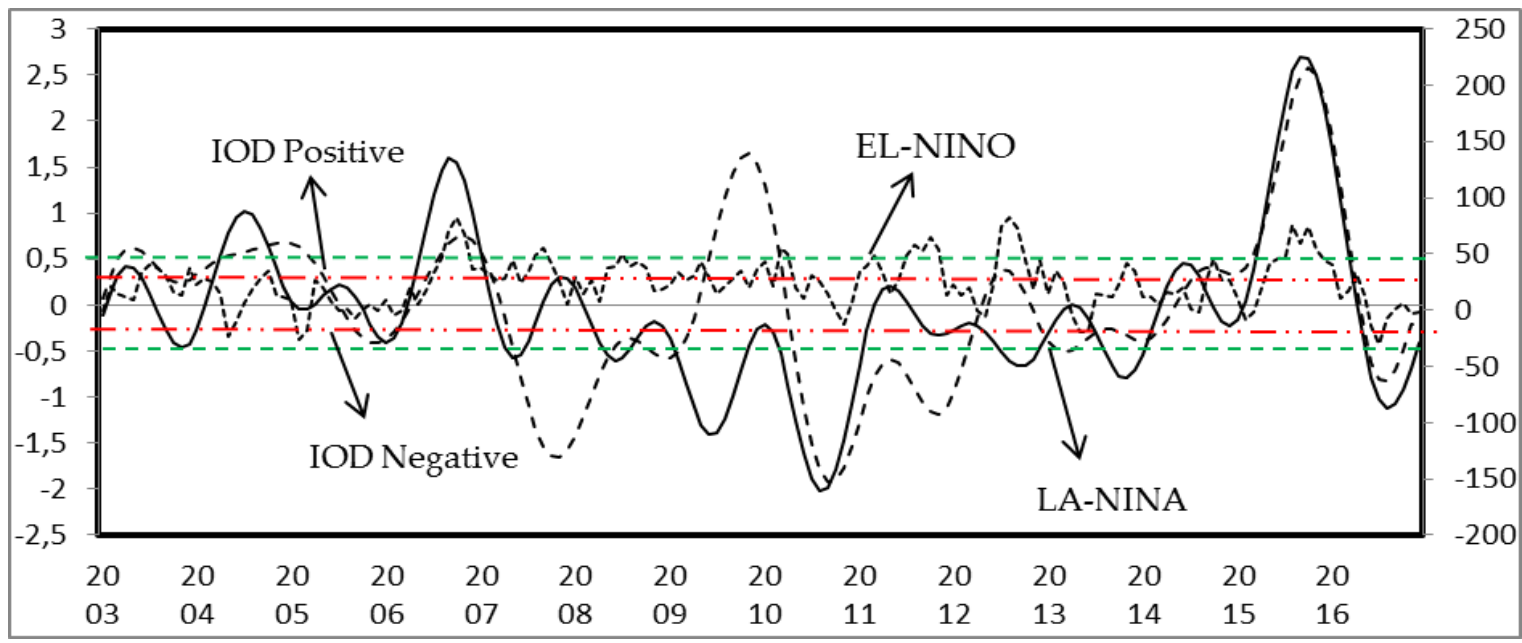

Gambar 10. Fluktuasi anomali NPP (Garis tebal), ENSO (Garis putus-putus) dan IOD (Garis titik-titik) (2003-2016) 
perbedaan pola pada tahun 2005, 2009, 2013 dan 2014 (Gambar 10), dimana pada saat nilai ENSO meningkat tetapi terjadi penurunan pada nilai NPP. Hal serupa juga disampaikan di dalam penelitian Sukresno dan Suniada (2016) yang menyatakan bahwa fenomena ENSO mempengaruhi NPP dengan nilai korelasi sebesar 0,33, dimana nilai korelasi yang kecil diakibatkan oleh melonjaknya nilai ENSO yang disertai dengan rendahnya nilai NPP pada tahun 2005.

Keterkaitan ENSO dengan NPP di Laut Banda dapat dilihat dari tingginya NPP pada bulan Agustus 2015 dan rendahnya nilai NPP pada bulan Desember 2010 (Gambar 10). Hal tersebut diindikasikan dengan adanya pengaruh fenomena ENSO (EL-Nino) yang kuat pada tahun 2015 (Gambar 10). Kondisi ini sesuai dengan pernyataan Suryani (2015) yang menyatakan bahwa terjadi fenomena EL-Nino yang berkepanjangan dan diprediksi mencapai puncaknya pada bulan Agustus sampai Desember 2015 yang menyebabkan peningkatan klorofil-a dan menjadikan potensi panen ikan juga lebih tinggi di daerah Sumatera bagian barat, Jawa bagian selatan, Sulawesi, dan Maluku bagian utara. Hal tersebut juga diperkuat oleh Ratnawati et al. (2016) yang menyatakan bahwa pada tahun 2015-2016 terjadi peristiwa EL-Nino yang sangat kuat dengan diiringi peningkatan nilai klorofil-a di Laut Banda. Rendahnya NPP pada Desember 2010 diindikasikan dengan adanya pengaruh fenomena ENSO (La Nina) yang kuat pada tahun tersebut. Pernyataan tersebut didukung oleh penelitian Assyakur dan Prasetia (2010) yang menyatakan

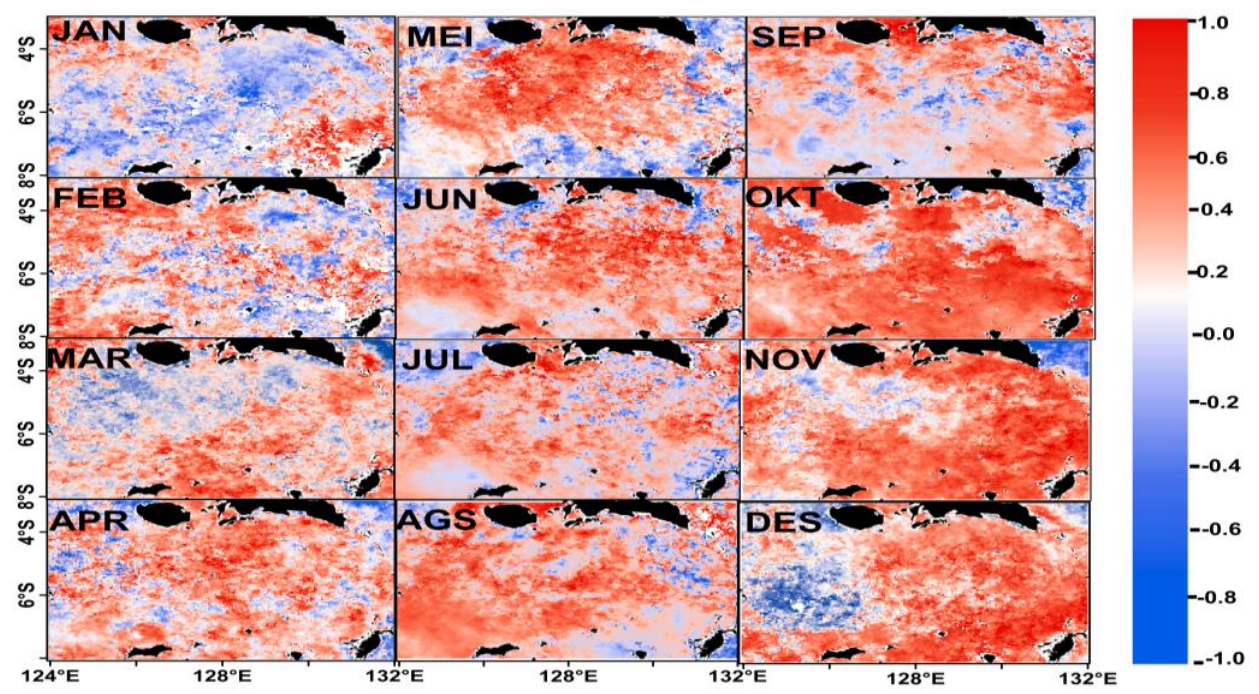

Gambar 11. Hasil korelasi spasial antara ENSO dan anomali produktivitas primer bersih di Laut Banda

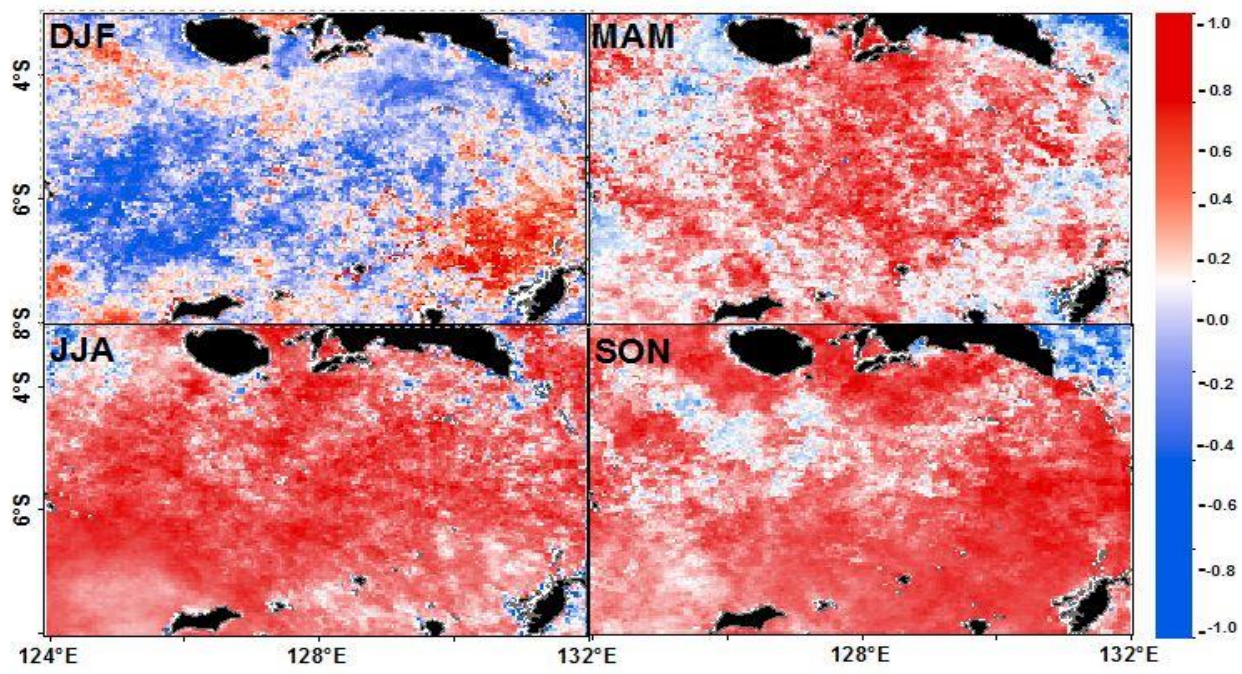

Gambar 12. Hasil korelasi musiman ENSO dan Produktivitas primer bersih di Laut Banda 
bahwa kejadian awal La Nina 2010 yaitu pada bulan April dan mengalami puncak pada bulan Agustus, dimana dampak dari peristiwa La Nina ini adalah suhu permukaan laut menjadi lebih hangat, pasokan klorofil-a menurun yang berdampak pada berkurangnya hasil tangkapan ikan.

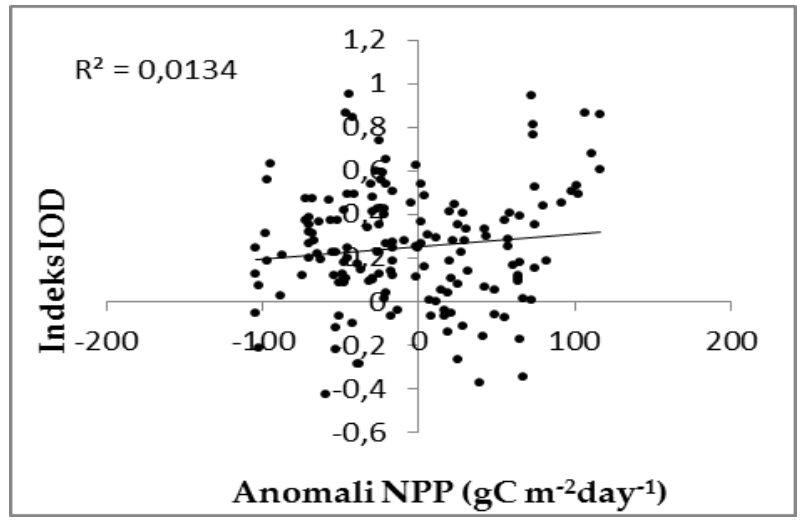

Gambar 13. Hubungan antara IOD dan Anomali Produktivitas primer bersih

Secara spasial rata-rata korelasi bulanan ENSO dan NPP dari bulan Januari hingga Desember dapat dilihat pada Gambar 11. Rata-rata korelasi bulanan ENSO dan NPP terkuat terjadi pada bulan Agustus dan terlemah pada bulan Januari. Korelasi ENSO dan NPP paling kuat terlihat pada bagian timur Laut Banda, dimana Laut Banda banyak menerima masukan massa air dari Samudra Pasifik melalui bagian timur Laut Banda (Ratnawati et al., 2016). Penelitian Kemili (2012) menyatakan bahwa wilayah timur Laut Banda paling banyak menerima pengaruh ENSO.

Secara musiman korelasi ENSO dan NPP dapat dilihat pada Gambar 12. Nilai rata-rata korelasi musiman ENSO dan NPP terkuat terjadi pada musim timur dan musim peralihan II di sebagian besar wilayah penelitian. Pada saat musim timur dan musim peralihan II diindikasikan terjadi fenomena ENSO (EL-Nino) dan proses upwelling di Laut Banda yang dibuktikan oleh terjadinya peningkatan nilai produktivitas primer bersih di Laut Banda pada saat musim timur. Hal ini sesuai dengan pernyataan Ratnawati et al. (2016) yang menyatakan bahwa terjadinya peristiwa EL-Nino beriringan dengan meningkatnya nilai klorofil-a di Laut Banda.

Hasil perhitungan hubungan IOD dengan NPP di Laut Banda menunjukkan bahwa adanya hubungan IOD terhadap NPP di Laut Banda dengan nilai korelasi yang tergolong lemah. Nilai koefisien determinasi antara IOD dan produktivitas primer bersih sebesar 0, 0134, sedangkan nilai korelasinya yaitu 0,23 (Gambar 13). Lemahnya korelasi IOD dengan NPP dibandingkan korelasi ENSO dengan NPP diperkirakan karena tingginya pengaruh ENSO dari Samudra Pasifik ke Laut Banda dibandingkan IOD yang berasal dari Samudra Hindia. Hal tersebut juga diduga karena banyaknya masukan massa air Samudra Pasifik ke Laut Banda. Sulaiman (2000) menyatakan bahwa Samudra Pasifik merupakan sumber utama massa air di Laut Banda. Gordon dan Susanto (2001) juga menyatakan bahwa massa air Laut Banda berasal dari Samudra Pasifik utara.

Hubungan IOD dan NPP dapat dilihat pada Gambar 10, dimana secara umum peningkatan NPP selalu beriringan dengan terjadinya IOD positif. Hal tersebut dapat dikaitkan dengan upwelling yang terjadi di Laut Banda. Kemili dan Putri (2012) menyatakan adanya fenomena IOD positif akan menyebabkan terjadinya upwelling yang ditandai dengan menipisnya lapisan thermoklin serta diikuti dengan menurunnya suhu dan meningkatnya klorofil-a.

Secara spasial korelasi IOD dan NPP terkuat pada bulan Oktober di seluruh perairan Laut Banda. Hal tersebut diduga karena adanya hubungan yang kuat antara tingginya NPP yang disertai dengan adanya fenomena IOD. Kemili dan Putri (2012) menyatakan bahwa IOD positif mengindikasikan terjadinya upwelling di wilayah Laut Banda. IOD positif terjadi karena adanya tekanan udara yang lebih tinggi di Laut Banda dibandingkan tekanan udara di Samudra Hindia Barat sehingga terjadi aliran udara dari wilayah tersebut ke Samudra Hindia barat (Hermawan dan Komalaningsih , 2010).

Tingginya korelasi IOD dan NPP pada musim timur terjadi di sebagian besar wilayah penelitian. Hal ini diduga disebabkan karena tingginya NPP pada musim timur yang disertai dengan adanya fenomena IOD. Adanya IOD (positif) menyebabkan terjadinya peristiwa upwelling. Begitu pula halnya pada musim peralihan II yang masih terkena pengaruh oleh musim timur. Lemahnya korelasi pada musim peralihan I diindikasikan dengan tidak adanya fenomena IOD. As-syakur (2011) menyatakan bahwa pada saat musim peralihan I efek IOD di Indonesia menghilang. 


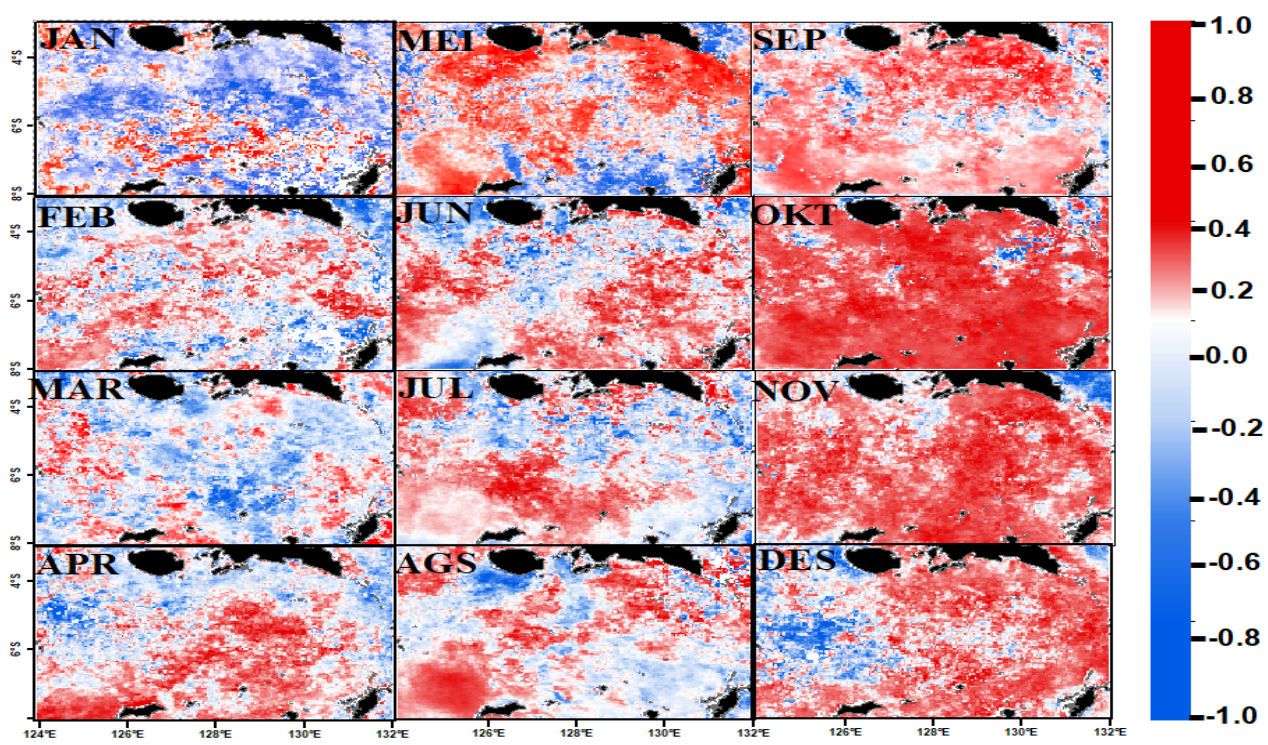

Gambar 14. Hasil Korelasi spasial IOD dan Produktivitas primer bersih di Laut Banda

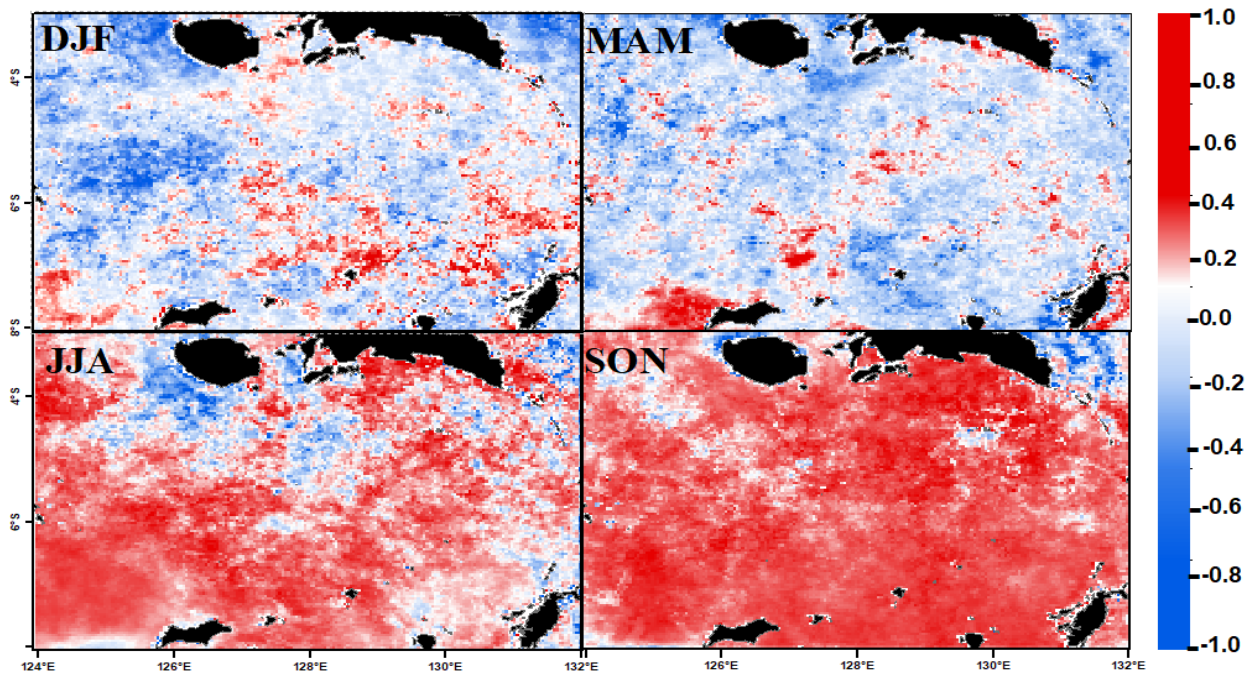

Gambar 15. Hasil korelasi musiman antara IOD dan Produktivitas primer bersih

\section{Simpulan}

Rata-rata nilai produktivitas primer bersih di Laut Banda selama 14 tahun mencapai $100 \mathrm{gCm}^{-2}$ day $^{-1}$ $1200 \mathrm{gCm}^{-2}$ day $^{-1}$, dengan puncak tertinggi produktivitas primer bersih berada pada musim timur. Tingginya nilai produktivitas primer bersih tesebut dikarenakan adanya peristiwa upwelling pada musim tersebut. Wilayah yang memiliki nilai produktivitas primer bersih tertinggi yaitu wilayah timur Laut Banda.

Hubungan antara ENSO dengan NPP di Laut Banda termasuk dalam kategori sedang dengan nilai korelasinya yaitu 0,556 . Keberadaan ENSO (EL-Nino) menyebabkan peningkatan produktivitas primer bersih di Laut Banda, sedangkan hubungan antara IOD dan NPP tergolong dalam kategori lemah dengan nilai korelasinya yaitu 0,262. Keberadaan IOD (IOD positif) hampir selalu beriringan dengan peningkatan produktivitas primer bersih di Laut Banda.

\section{Ucapan Terimakasih}

Terimakasih penulis ucapkan kepada Ranu Fajar Maharta dan Dharma Raharja yang telah membantu dalam kelancaran penelitian ini.

\section{Daftar Pustaka}

As-syakur, A. R. (2011). Pola spasial hubungan curah hujan dengan ENSO dan IOD di Indonesia-Observasi 
menggunakan data TRMM 3B43. In Wikantika, K. \& Fajri, L. (Eds.). Bunga Rampai Penginderaan Jauh Indonesia; (Seri-1). Bandung, Indonesia: Pusat Penginderaan Jauh Institut Tekhnologi Bandung (ITB), pp. 92-107.

As-syakur, A. R., \& Prasetia, R. (2010). Pola spasial anomali curah hujan selama Maret sampai Juni 2010 Di Indonesia; Komparasi data TRMM Multisatellite Precipitation Analysis (TMPA) $3 B 43$ dengan stasiun pengamat hujan. Dalam Prosiding Penelitian Masalah Lingkungan di Indonesia 2010; Buku 2. Denpasar, Indonesia, 29 Juli 2010 (pp. 505-516).

Behrenfeld, M. J., \& Falkowski, P. G. (1997). Photosynthetic rates derived from satellite-based chlorophyll concentration. Limnology and oceanography, 42(1), 1-20.

Cai, S., Wu, Y., Xiang, N., Zhong, Z., He, J., Shi, L., \& Xu, F. (2012). Detrending knee joint vibration signals with a cascade moving average filter. In Proceedings of the 34th Annual International Conference of the IEEE Engineering in Medicine and Biology Society (EMBC'12). San Diego, California USA, 28 August - 1 September 2012 (pp. 4357-4360).

Deng, Y., Zhang, Y., Li, D., Shi, K., \& Zhang, Y. (2017). Temporal and Spatial Dynamics of Phytoplankton Primary Production in Lake Taihu Derived from MODIS Data. Remote Sensing, 9(3), 1-18.

Fauzia, H. K. (2011). Pengaruh Fenomena IODM Terhadap Pola Penyebaran Klorofil di Perairan Barat Sumatra. Skripsi. Bogor, Indonesia: Departemen Ilmu dan Teknologi Kelautan, Institut Pertanian Bogor.

González-Rodríguez, E., Trasviña-Castro, A., GaxiolaCastro, G., Zamudio, L., \& Cervantes-Duarte, R. (2012). Net primary productivity, upwelling and coastal currents in the Gulf of Ulloa, Baja California, México. Ocean Science, 8(4), 703-711.

Gordon, A. L., \& Susanto, R. D. (2001). Banda Sea surface-layer divergence. Ocean Dynamics, 52(1), 2-10.

Hermawan, E., \& Komalaningsih, K. (2010). Karakteristik Indian Ocean Dipole Mode di Samudera Hindia Hubungannya dengan Perilaku Curah Hujan di Kawasan Sumatera Barat Berbasis Analisis Mother Wavelet. Jurnal Sains Dirgantara, 5(2), 109-129.

Hidayat, R., \& Ando, K. (2014). Variabilitas Curah Hujan Indonesia dan Hubungannya dengan ENSO/IOD: Estimasi Menggunakan Data JRA-25/JCDAS. Jurnal Agromet Indonesia, 28(1), 1-18.

Ilahude, A. G., Komar, K., \& Mardanis, M. (1990). On the hydrology and productivity of the northern Arafura Sea. Netherlands Journal of Sea Research, 25(4), 573-583.

Ishizaka, J., Siswanto, E., Itoh, T., Murakami, H., Yamaguchi, Y., Horimoto, N., \& Saino, T. (2010). Verification of vertically generalized production model and estimation of primary production in
Sagami Bay, Japan. Journal of oceanography, 63(3), 517524.

JAMSTEC. Japan Agency for Marine-Earth Science and Technology. n.d. Dipole Mode Index. [online] Tersedia di: http://www.jamstec.go.jp/frcgc/research

/d1/iod/iod/dipole_mode_index.html, [diakses: 30 Oktober 2016].

Joo, H., Son, S., Park, J. W., Kang, J. J., Jeong, J. Y., Lee, C. I., \& Lee, S. H. (2015). Long-Term pattern of primary productivity in the east/japan sea based on ocean color data derived from MODIS-Aqua. Remote Sensing, 8(1), 1-13.

Kemili, P., \& Putri, M. R. (2012). Pengaruh Durasi dan Intensitas Upwelling Berdasarkan Anomali Suhu Permukaan Laut terhadap Variabilitas Produktivitas primer bersih di Perairan Indonesia. Jurnal Ilmu dan Teknologi Kelautan Tropis, 4(1), 66-79.

Lee, Z., Marra, J., Perry, M. J., \& Kahru, M. (2015). Estimating oceanic primary productivity from ocean color remote sensing: A strategic assessment. Journal of Marine Systems, 149, 50-59.

Levinton, J. S. (2013). Marine Biology: Function, Biodiversity, Ecology. (4th ed.). Oxford, UK: Oxford University Press.

Martono, M. (2016). Dampak El Niño 1997 Dan El Niño 2015 Terhadap Konsentrasi Klorofil-A Di Perairan Selatan Jawa Dan Bali-Sumbawa. Majalah Ilmiah Globe, 18(1), 01-08.

Merina, G., \& Zakaria, I. J. (2016). Produktivitas Primer Fitoplankton Dan Analisis Fisika Kimia Di Perairan Laut Pesisir Barat Sumatera Barat. METAMORFOSA Journal of Biological Sciences, 3(2), 112-119.

NASA. National Aeronautics and Space Administration. (2006). Airs QA Subset. [Online] Tersedia di: disc.gsfc.nasa.gov/AIRS/airs_QA_subset.shtml, [diakses: 30 Oktober 2016].

NASA. National Aeronautics and Space Administration. (2008). Ocean Color. [Online] Tersedia di: http:// www.Oseancolor.gsfc.nasa.gov/, [diakses: 30 Oktober 2016].

NOAA. National Oceanic and Atmospheric Administration. n.d. Ocean Nino Index. [Online] Tersedia di: http://www.ncdc.noaa.gov/ teleconnections /enso / indicators/sst.php, [diakses: 30 Oktober 2016].

Pusparini, N., Prasetyo, B., \& Widowati, I. (2017). The Thermocline Layer and Chlorophyll-a Concentration Variability during Southeast Monsoon in the Banda Sea. In IOP Conference Series: Earth and Environmental Science, 55(1), 1-12.

Ratnawati, H.I., Hidayat, R., Bey, A., June, T. (2016). Upwelling di Laut Banda dan Pesisir Selatan Jawa serta Hubungannya dengan ENSO dan IOD. OmniAkuatika, 12(3), 119-130. 
Schalk, P. H. (1987). Monsoon-related changes in zooplankton biomass in the eastern Banda Sea and Aru Basin. Biological oceanography, 5(1), 1-12.

Sediadi, A. (2010). Effek Upwelling Terhadap Kelimpahan dan distribusi fitoplankton di perairan laut banda dan sekitarnya. Makara Journal of Science, 8(2), 43-51.

Shang, S. L., Behrenfeld, M. J., Lee, Z. P., O'Malley, R. T., Wei, G. M., Li, Y. H. (2010). Comparison of primary productivity models in the Southern Ocean-preliminary results. In Proceedings of the SPIE Vol. 7678, Ocean Sensing and Monitoring II, 767808 (20 April 2010; p. 767808). doi: https://doi.org/10.1117/12.853631.

So'langi, L. N. \& Nuryadi. (2015). Hubungan Curah Hujan Dengan Fenomena Global (SOI, Nino 4, Nino 3.4 dan Nino West) di Wilayah Papua dan Papua Barat. Jurnal Meteorologi Klimatologi dan Geofisika, 2(2), 176-185.

Sugiyono. (2011). Metode Penelitian Kuantitatif Kualitatif dan RED. Bandung: ALFABET.

Sukresno, B. \& Suniada, K.I. (2016). Observasi Pengaruh ENSO Terhadap Produktivitas primer bersih Dan Potensi Perikanan Dengan Menggunakan Data Satelit Di Laut Banda. Majalah Ilmiah Globe, 10(2), 97-107.

Sukresno, B., \& Kasa, I. W. (2008). Dynamical analysis of Banda Sea concerning with EL-Nino, Indonesian Through Flow and Monsoon by using satellite data and numerical model. Ecotrophic: Journal of Environmental Science, 3(2), 87-91.
Sulaiman, A. (2000). Turbulensi Laut Banda, Studi Pendahuluan ARLINDO Microstructure. Jakarta, Indonesia: Direktorat Teknologi Inventarisasi Sumberdaya Alam (TISDA), Badan Pengkajian dan Penerapan Teknologi (BPPT).

Suryani, A.S. (2015). Ancaman El-nino 2015. Pusat Pengkajian, Pengolahan data dan Informasi (P3DI), 7(13), 9-12.

Tadjuddah, M., \& Mustafa, A. (2017). Sebaran suhu permukaan laut dan tracking daerah penangkapan Ikan Cakalang di Perairan Barat Laut Banda.Jurnal Manajemen Sumber Daya Perairan, 2(1), 41-49.

Tarigan, M. S. (2010). Pengaruh Musim Terhadap Fluktuasi Kadar Fosfat Dan Nitrat Di Laut Banda. Makara Journal of Science, 7(2), 82-89.

Waileruny, W., Wiyono, E. S., Wisodo, S. H., Purbayanto, A., \& Nurani, T. W. (2014). Monsoon and Skipjack Fishing Ground in The Banda Sea and Its Surrounding Moluccas Province.Jurnal Teknologi Perikanan dan Kelautan, 5(1), 41-54.

Yen, K. W., \& Lu, H. J. (2016). Spatial-temporal variations in primary productivity and population dynamics of skipjack tuna Katsuwonus pelamis. Fisheries science, 82(4), 563-571.

Yulia, K. E. M. (2013). Variabilitas Klorofil-a dan Beberapa Parameter Oseanografi Hubungannya Dengan Monsoon, ENSO dan IOD di Laut Banda. Tesis. Bogor, Indonesia: Program Studi Magister Sains, Program Pascasarjana Institut Pertanian Bogor.

(C) 2018 by the authors; licensee Udayana University, Indonesia. This article is an open access article distributed under the terms and conditions of the Creative Commons Attribution license (http://creativecommons.org/licenses/by/3.0/). 